\title{
Temporal variability in dynamic and colloidal metal fractions determined by high resolution in situ measurements in a UK estuary
}

\author{
Charlotte B. Braungardt*, Kate A. Howell ${ }^{1}$, Alan D. Tappin, Eric P. Achterberg ${ }^{2}$ \\ School of Geography, Earth and Environmental Sciences, University of Plymouth, Devon PL4 8AA, UK
}

\section{A R T I C L E I N F O}

\section{Article history:}

Received 26 November 2010

Received in revised form 24 March 2011

Accepted 27 March 2011

Available online 6 May 2011

\section{Keywords:}

Biogeochemistry

Metal speciation

Voltammetry

Microsensor

Coastal water

In situ monitoring

\begin{abstract}
A B S T R A C T
In recent environmental legislation, such as the Water Framework Directive in the European Union (WFD, $2000 / 60 / E C$ ), the importance of metal speciation and biological availability is acknowledged, although analytical challenges remain. In this study, the Voltammetric In situ Profiler (VIP) was used for high temporal resolution in situ metal speciation measurements in estuarine waters. This instrument simultaneously determines $\mathrm{Cd}, \mathrm{Cu}$ and $\mathrm{Pb}$ species within a size range $(\mathrm{ca} .<4 \mathrm{~nm}$ ) that is highly relevant for uptake by organisms. The colloidal metal fraction can be quantified through a combination of VIP measurements and analyses of total dissolved metal concentrations.

VIP systems were deployed over tidal cycles in a seasonal study of metal speciation in the Fal Estuary, southwest England. Total dissolved concentrations were $4.97-315 \mathrm{nM} \mathrm{Cu}, 0.13-8.53 \mathrm{nM} \mathrm{Cd}$ and $0.35-5.75 \mathrm{nM} \mathrm{Pb}$. High proportions of $\mathrm{Pb}(77 \pm 17 \%)$ and $\mathrm{Cu}(60 \pm 25 \%)$ were present as colloids, which constituted a less important fraction for $\mathrm{Cd}(37 \pm 30 \%)$. The study elucidated variations in the potentially toxic metal fraction related to river flow, complexation by organic ligands and exchanges between dissolved and colloidal phases and the sediment. Based on published toxicity data, the bioavailable Cu concentrations $(1.7-190 \mathrm{nM})$ in this estuary are likely to severely compromise the ecosystem structure and functioning with respect to species diversity and recruitment of juveniles. The study illustrates the importance of in situ speciation studies at high resolution in pursuit of a better understanding of metal (bio)geochemistry in dynamic coastal systems.
\end{abstract}

(c) 2011 Elsevier Ltd. All rights reserved.

\section{Introduction}

The European coastal zone has a substantial ecological, recreational and economic value (European Environment Agency, 2005). Nevertheless, contamination of European coastal seas is widespread as a result of the urbanisation of coastal margins, industrialisation and intensification of agriculture. Although land-based inputs of metals (e.g. $\mathrm{Cd}, \mathrm{Cu}, \mathrm{Pb}$ ) to marine waters are reported to have been reduced recently, this has not necessarily resulted in lower concentrations in marine biota (European Environment Agency, 2003). Furthermore, emerging pressures may add to the metal burden in coastal waters. First, the marked increase in mariculture over the last few decades has been accompanied by a rise in the use of copper-based anti-fouling paints (Braithwaite et al., 2007). Secondly, 20\% of Europe's coastline is

\footnotetext{
* Corresponding author. Tel.: +44 1752 584577; fax: +44 175258471.

E-mail addresses: A.Tappin@plymouth.ac.uk, C.Braungardt@plymouth.ac.uk (C.B. Braungardt), Kate.Howell@nanotecture.co.uk (K.A. Howell), eric@noc.soton.ac. uk (E.P. Achterberg).

1 Nanotecture Ltd., Epsilon House, Southampton Science Park, Southampton SO16 7NS, UK.

2 School of Ocean and Earth Science, National Oceanography Centre Southampton, University of Southampton, SO14 3ZH, UK.
}

being actively eroded and this may increase as a result of projected sea level rise and increased storminess, whereby medium to long-term impacts include the remobilisation of historically metal-contaminated coastal sediments (European Environment Agency, 2005). Thirdly, increasing atmospheric $\mathrm{CO}_{2}$ concentrations may result in a reduction in seawater $\mathrm{pH}$ and enhanced release of metals from sediments. Increasing acidity may also alter metal speciation, with unpredictable consequences, particularly with respect to metal bioavailability and toxicity (The Royal Society, 2005).

The biogeochemical role of trace metals is determined by their physical and chemical speciation, encompassing particulate, colloidal and truly dissolved forms. Colloids are generally viewed as organic-rich solid-in-liquid dispersions with a size in the range 1-1000 nm (Stolpe et al., 2010). Truly dissolved metals include free metal ions and simple inorganic and organic metal complexes that are considered to be readily assimilated by (micro)biota via transport across cellular plasma membranes (Buffle and Tercier-Waeber, 2005; Slaveykova and Wilkinson, 2005). In estuaries, colloids play an important role in the exchange processes of metals between the sediment and the water column and in controlling metal speciation. For example, Powell et al. (1996) reported colloidal $\mathrm{Cu}$ as the dominant fraction of this metal in 
low salinity estuarine waters. Complexes of $\mathrm{Cu}$ with dissolved organic ligands have been widely reported to dominate the total dissolved $(0.45 \mu \mathrm{m}$ pore size filtrate) $\mathrm{Cu}$ fraction at enhanced salinities, whereby a high proportion (40-94\%) of the organically complexed $\mathrm{Cu}$ is associated with colloids (Powell et al., 1996; Wen et al., 1999; Waeles et al., 2008). Copper speciation varies widely between estuaries and within estuaries with tides and seasons, depending on the nature and concentration of organic matter present (Waeles et al., 2008). In saline systems featuring low dissolved organic matter concentrations, copper carbonate species are likely to be the most important form of dissolved $\mathrm{Cu}$ (Chester, 2003). In rivers, $\mathrm{Cd}$ is mostly present as aqueous $\mathrm{Cd}(\mathrm{II})$, although significant colloidal fractions can occur (Powell et al., 1996; Wen et al., 1999; Howell et al., 2006). In more saline waters, chlorocomplexed Cd typically dominates the dissolved speciation of the metal (Chester, 2003), but colloidal Cd can be important at midto high salinities (34-82\% of total dissolved), where interaction of Cd with Fe/Mn (oxy)hydroxide and/or organic colloids may occur (Wells et al., 1998; Wen et al., 1999; Waeles et al., 2008). Dissolved $\mathrm{Pb}$ in fresh waters strongly associates with carbonates (Chester, 2003) and also with large iron-, and to a lesser extent, carbon-rich colloids greater than $10 \mathrm{kDa}$ (ca. $10 \mathrm{~nm}$ ) (Lyvén et al., 2003). Colloidal iron oxides, hydroxides and sulphides may be the dominant absorbent phases for $\mathrm{Pb}$ in saline waters, as indicated by the high colloidal $\mathrm{Pb}$ fraction of total dissolved $\mathrm{Pb}$ observed in some estuaries (59-99\%; Braungardt et al., 2009; Waeles et al., 2008).

Metal-colloid associations are studied typically by employing a range of separation techniques (e.g. ultrafiltration, centrifugation, field flow fractionation) that require the collection of samples and their subsequent processing in the laboratory. However, in order to provide a more detailed understanding of metal behaviour, toxicity and fate in dynamic coastal systems, their speciation profile should be studied at high temporal resolution and preferably in the field. Recent developments in in situ analytical instrumentation for trace metal speciation monitoring allow such field measurements of metal speciation. In situ simultaneous measurements of dynamic $\mathrm{Cd}(\mathrm{II}), \mathrm{Cu}(\mathrm{II})$ and $\mathrm{Pb}(\mathrm{II})$ species in coastal marine waters using the Voltammetric In situ Profiler (VIP, Idronaut, Milan) system (the term 'dynamic' is defined below) have been reported by, e.g. Howell et al. (2003), Tercier-Waeber et al. (2005) and Braungardt et al. (2009).

The aims of this study were to (i) investigate the speciation of $\mathrm{Cd}, \mathrm{Cu}$ and $\mathrm{Pb}$ in an estuarine system contaminated by historic metalliferous mining and continued inputs of metal-rich acid mine waters, (ii) elucidate temporal differences in metal speciation and (iii) relate speciation information to biological availability. To this end, VIP instruments were deployed in a seasonal study in estuarine waters for high resolution monitoring of $\mathrm{Cu}, \mathrm{Cd}$ and $\mathrm{Pb}$ speciation over full tidal cycles.

\section{Experimental}

\subsection{VIP instrumentation}

The VIP is designed for short and medium-term (up to 3 weeks) monitoring tasks and comprises of fully submersible (500 m) components for sample transport (peristaltic pump), sample analysis (3-electrode voltammetric system) and data management (hardware, firmware, data memory). The flow-through cell houses within the sample pathway a working electrode and a platinum counter electrode. The working electrode is a gel-integrated microelectrode (GIME), which consists of an array of 100 interconnected Ir-based micro-disc electrodes onto which mercury is electroplated prior to use. The reference electrode is a miniaturised
$\mathrm{Ag} / \mathrm{AgCl} / \mathrm{KCl}$ saturated gel electrolyte electrode and it is electrically connected to the sample pathway via a system of two zirconium oxide ceramic bridges embedded into bridge electrolyte gel $(1 \mathrm{M}$ $\mathrm{NaNO}_{3}$ in agarose $\left.1.5 \% \mathrm{w} / \mathrm{v} \mathrm{LGL}\right)$. A gel membrane (1.5\% (w/v) agarose LGL, $300 \mu \mathrm{m}$ thick) prevents fouling of the working electrode surface during deployment in natural waters. A full description of the system and its preparation for use is detailed elsewhere (Tercier-Waeber et al., 2002; Braungardt et al., 2009).

The VIP quantifies a fraction of the conventional total dissolved trace metal pool using size separation, whereby the metal flux towards the working electrode, measured as an electrical current, is directly proportional to the diffusion coefficient of the analyte metal species and negligible for metal species of a size $>4 \mathrm{~nm}$. This enables the direct voltammetric analysis of what is termed the dynamic metal fraction, which includes free metal ions as well as sufficiently labile and mobile inorganic and organic metal complexes of a few nanometres in size. The dynamic fraction may be readily biologically available because dynamic metal complexes can dissociate within the time it takes to diffuse from the bulk medium to the cell surface receptor sites of organisms (Slaveykova and Wilkinson, 2005). The non-dynamic fraction, comprising metals associated with biopolymers, macromolecules and inorganic and organic colloids, is excluded from analysis (Buffle and Tercier-Waeber, 2005). The concentration of metal in the nondynamic, or colloidal, fraction was calculated as the difference between the dynamic concentration and the total dissolved metal concentration, defined by conventional filtration $(0.4 / 0.45 \mu \mathrm{m}$ pore size) of discrete samples. Here, the dynamic dissolved metal is termed $\mathrm{Me}_{\mathrm{dyn}}$, the total dissolved metal $\mathrm{Me}_{\text {tot }}$ and the colloidal metal $\mathrm{Me}_{\text {coll- }}$.

\subsection{Reagents and apparatus}

The preparation and handling of reagents, samples and apparatus was carried out using trace metal clean techniques in protected environments, such as a covered bench on board ship and Class100 laminar flow cabinets in laboratories. Water was purified by ion exchange (de-ionised water, Milli-Q system, Millipore, 18.2 $\mathrm{M} \Omega \mathrm{cm}^{-1}$ ) and used for the preparation of all aqueous solutions. Reagents were AR grade (Alpha Aesar, VWR, Poole, UK) unless stated otherwise. Nitric acid and hydrochloric acid were purified by sub-boiling distillation (sub- $\mathrm{HNO}_{3}$, sub-HCl). Clean ammonium hydroxide was prepared by isothermal distillation (iso- $\left.\mathrm{NH}_{4} \mathrm{OH}\right)$. Metal standards $(10 \mu \mathrm{m} \mathrm{Cu}(\mathrm{II}), 1 \mu \mathrm{m} \mathrm{Cd}(\mathrm{II})$ and $\mathrm{Pb}(\mathrm{II})$ ) were prepared from Spectrosol stock solutions $\left(10 \mathrm{~g} \mathrm{~L}^{-1}\right.$, Merck Chemicals) by serial dilution, and acidified to $\mathrm{pH}<2$ with either sub- $\mathrm{HNO}_{3}$ (for voltammetric analysis with the VIP and a glassy carbon rotating disc electrode on a VA 663 Stand (Metrohm, Switzerland) interfaced with an $\mu$-Autolab, Ecochemie) or with sub- $\mathrm{HCl}$ for analysis with a hanging mercury drop electrode on a VA 663 Stand. Solutions of mercuric acetate $(5 \mathrm{mM})$ in perchloric acid $(10 \mathrm{mM})$, aqueous mercuric nitrate $(2 \mathrm{mM})$, potassium thiocyanate $(1 \mathrm{M})$, sodium nitrate $(0.05$ and $1.0 \mathrm{M}$, Trace select, Sigma Aldrich, UK), 8-hydroxyquinoline stock solution $(0.01 \mathrm{M}, 99 \%$ grade, Merck Chemicals), HEPES pH buffer solution (1 M, biochemical grade, Merck Chemicals) and ammonium acetate pH buffer ( $1 \mathrm{M})$ were prepared, purified and the $\mathrm{pH}$ adjusted where required (Braungardt et al., 2009).

Glass- and plastic-ware were decreased (2\% Decon, $>24 \mathrm{~h}$; $\mathrm{NaOH}$ pH10, >24 h), acid-washed $(1.2 \mathrm{M} \mathrm{HCl},>24 \mathrm{~h} ; 1.4 \mathrm{M}$ $\mathrm{HNO}_{3},>4 \mathrm{~h}$ ) and thoroughly rinsed between steps with deionised water. Glass-ware was combusted $\left(450^{\circ} \mathrm{C}, 6 \mathrm{~h}\right)$ as a final step. All glass fibre filters $(\mathrm{GF} / \mathrm{F}$, nominal pore size $0.7 \mu \mathrm{m}$, Whatman) were combusted $\left(450^{\circ} \mathrm{C}, 4 \mathrm{~h}\right)$ and polycarbonate membrane filters $(0.4 \mu \mathrm{m}$ pore size, Whatman) were acid-washed (1.2 M HCl, >24 h). 


\subsection{Study area}

Restronguet Creek is located within the larger macro-tidal Fal Estuary, which extends $18 \mathrm{~km}$ inland from its mouth to its tidal limit (Fig. 1). The River Carnon is the main freshwater input to Restronguet Creek and water from the Creek is tidally exchanged with water from the outer Fal Estuary, which is known as Carrick Roads. The extensive inter-tidal mudflats (Fig. 1A) and saltmarshes of the area are heavily contaminated with $\mathrm{As}, \mathrm{Cu}, \mathrm{Fe}, \mathrm{Pb}$ and $\mathrm{Zn}$ as a result of long-term run-off of acid mine drainage and a history of tin streaming. Average total dissolved concentrations of $\mathrm{Cd}$ and $\mathrm{Cu}$ in the River Carnon are ca. 40 and $3800 \mathrm{nM}$, respectively (Langston et al., 2003), while sediments in the Creek contain up to $80 \mu \mathrm{mol} \mathrm{g}^{-1} \mathrm{Cu}, 48 \mathrm{nmol} \mathrm{g}^{-1} \mathrm{Cd}$ and $2.8 \mu \mathrm{mol} \mathrm{g}^{-1} \mathrm{~Pb}$ (Langston et al., 2003; Pirrie et al., 2003). These concentrations exceed the Interim Marine Sediment Quality Guidelines (ISQG; $249 \mathrm{nmol} \mathrm{g}^{-1}$
$\mathrm{Cu}, 6.25 \mathrm{nmol} \mathrm{g}^{-1} \mathrm{Cd}$ and $\left.144 \mathrm{nmol} \mathrm{g}^{-1} \mathrm{~Pb}\right)$. Continued adverse effects on the ecology of Restronguet Creek, as well as adaptation to contamination by biota, have been widely reported (Warwick, 2001; Burlinson and Lawrence, 2007).

\subsection{Sampling}

Measurements over a single tidal cycle were undertaken at Restronguet Point (RP), at the junction of Restronguet Creek and Carrick Roads (Fig. 1), in June, August and December 2002 and March, April and July 2003. Surveys coincided with spring tides (tidal range 3.7-4.7 m), except for August 2002 (tidal range $2.3 \mathrm{~m}$ ). During each period, two VIP instruments were deployed simultaneously in situ; one to determine $\mathrm{Cu}_{\mathrm{dyn}}$ concentrations and the other to quantify $\mathrm{Cd}_{\mathrm{dyn}}$ and $\mathrm{Pb}_{\mathrm{dyn}}$. At the same time, discrete samples were collected using a manually deployed sampler or a

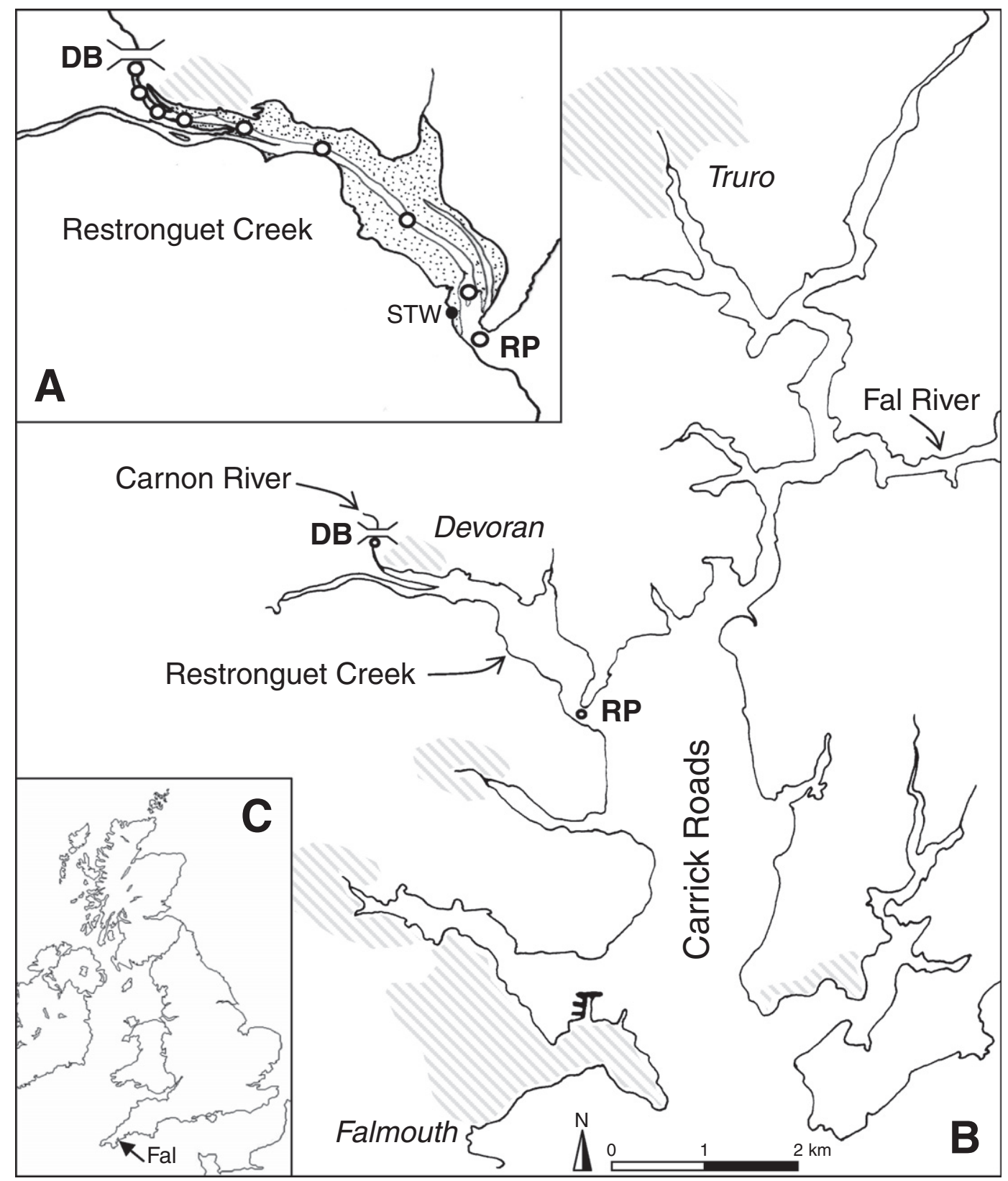

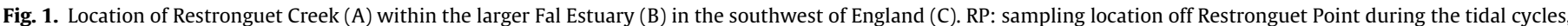

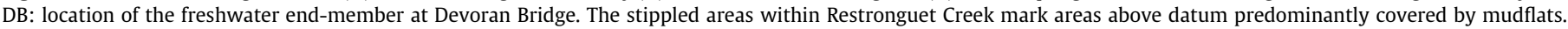

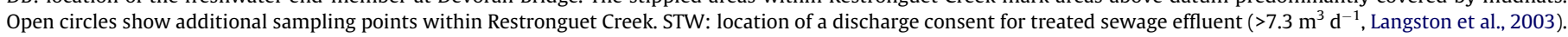


high-volume peristaltic pump for the determination of total concentrations of $\mathrm{Cu}_{\text {tot }}, \mathrm{Cd}_{\text {tot }}$ and $\mathrm{Pb}_{\text {tot }}$, salinity, suspended particulate matter (SPM), nitrate + nitrite, ortho-phosphate, dissolved organic carbon (DOC) and suspended chlorophyll $a$. Discrete samples were collected at $1.5 \mathrm{~m}$ below surface, the same depth at which the in situ sample inlet of the VIP was located. At Restronguet Point, the water column was well mixed. Master variables (salinity, $\mathrm{pH}$ (calibrated using NBS buffers), dissolved oxygen saturation, turbidity) were also determined, using calibrated hand-held or CTD instrumentation. A sample representing the freshwater endmember was collected from the River Carnon at Devoran Bridge (Fig. 1) during the latter five surveys. In April and July 2003, discrete samples were also collected along an axial transect of the Restronguet Creek (Fig. 1A).

\subsection{Quantification}

\subsubsection{Dynamic dissolved metals}

Laboratory and in situ determinations of $\mathrm{Cu}(\mathrm{II}), \mathrm{Cd}(\mathrm{II})$ and $\mathrm{Pb}(\mathrm{II})$ concentrations by VIP were carried out as described in Braungardt et al. (2009). The analysis included a pre-concentration step (520 min), during which a specific deposition potential was applied (e.g. $-1270 \mathrm{mV}$ in de-oxygenated $\mathrm{NaNO}_{3}$ electrolyte, between -1300 and $-1100 \mathrm{mV}$ in seawater). Subsequently, two square wave anodic scans (pulse amplitude, $25 \mathrm{mV}$; step amplitude, $8 \mathrm{mV}$; frequency, $50 \mathrm{~Hz}$ ) to a more positive potential (e.g. $+150 \mathrm{mV}$ in $\mathrm{NaNO}_{3}$ or $-80 \mathrm{mV}$ in seawater) were carried out to determine the stripping and background currents, respectively. Calibrations were carried out in the laboratory before and after each measurement series (laboratory or in situ) using deoxygenated mixed standards $(0.75-2.5 \mathrm{nM} \mathrm{Cd}$ and $\mathrm{Pb}, 3-20 \mathrm{nM}$ $\mathrm{Cu})$ in $\mathrm{NaNO}_{3}(0.1 \mathrm{M})$. The sensitivity of the signal to changes in pre-concentration time, temperature and ionic strength have been discussed elsewhere (Howell et al., 2003), and appropriate adjustments were made during the quantification of the current peak for each analyte. The adjusted peak height is proportional to the concentration. The analytical limit of detection in seawater at $20 \mathrm{~min}$ pre-concentration time (defined as $3 \sigma$ ) was $23 \mathrm{pM}$ for $\mathrm{Cd}, 23 \mathrm{pM}$ for $\mathrm{Pb}$ and $1.13 \mathrm{nM}$ for $\mathrm{Cu}$.

\subsubsection{Total dissolved metals}

Samples for total dissolved metals were filtered $(0.4 \mu \mathrm{m}$ pore size filters) into $250 \mathrm{~mL}$ LDPE bottles and stabilised at $\mathrm{pH} 2$ with sub- $\mathrm{HCl}(250 \mu \mathrm{L})$. In order to remove potentially interfering dissolved organic matter prior to analysis the samples were UVirradiated for $5 \mathrm{~h}$ (in $30 \mathrm{~mL}$ quartz tubes) after addition of $\mathrm{H}_{2} \mathrm{O}_{2}$ (8.8 M, final concentration) using a $400 \mathrm{~W}$ medium pressure $\mathrm{Hg}$ vapour lamp (Photochemical Reactors, Slough). The $\mathrm{pH}$ of the acidified samples was raised (using iso- $\mathrm{NH}_{4} \mathrm{OH}$ ) to a level appropriate for the electrochemical method employed. Concentrations of $\mathrm{Cd}_{\text {tot }}, \mathrm{Cu}_{\text {tot }}$ and $\mathrm{Pb}_{\text {tot }}$ were determined using anodic stripping voltammetry $(\mathrm{Cd}$ : thin-film mercury electrode; $\mathrm{Cd}, \mathrm{Pb}$ and $\mathrm{Cu}$ : VIP) and by adsorptive cathodic stripping voltammetry (Cu: hanging mercury drop electrode). The accuracy of the $\mathrm{Cd}_{\text {tot }}, \mathrm{Cu}_{\text {tot }}$ and $\mathrm{Pb}_{\text {tot }}$ analyses by the VIP was verified using certified reference materials for river, estuarine and coastal waters (Braungardt et al., 2009).

\subsubsection{Salinity, nitrate + nitrite and ortho-phosphate, DOC and chlorophyll a}

Salinity in the discrete samples was determined using a salinometer (Guildline, Autosal). Suspended particulate matter was collected on pre-weighed glass fibre filters $(\mathrm{GF} / \mathrm{F})$, rinsed with a few $\mathrm{mL}$ of de-ionised water to remove sea salts, and stored at $-20^{\circ} \mathrm{C}$. Filters were subsequently air-dried and SPM determined by gravimetry. Nitrate + nitrite and ortho-phosphate were deter- mined on filtered $(\mathrm{GF} / \mathrm{F})$ samples. Filtrates $(25 \mathrm{~mL})$ were transferred to $30 \mathrm{~mL}$ LDPE sealable bottles and stored at $-20^{\circ} \mathrm{C}$ until analysis by colorimetry using a segmented flow analyser (Skalar $\left.S N^{\text {plus }}\right)$. Water samples for DOC analysis were filtered using ashed GF/F filters and the filtrates $(20 \mathrm{~mL})$ transferred to $40 \mathrm{~mL}$ glass vials (TOC Free, Nalgenunc). Filtrates were acidified to ca. pH 2 using $6 \mathrm{M} \mathrm{HCl}(20 \mu \mathrm{L})$ and stored at $-20^{\circ} \mathrm{C}$ until analysis by high temperature catalytic combustion using a Shimadzu TOC 5000A total carbon analyser (Badr et al., 2003). DOC measurements in certified reference material (CRM; US National Science Foundation/University of Miami, deep Sargasso Seawater, Batch 2, 2000) were $46.7 \pm 6.8 \mu \mathrm{M}$, and in good agreement with the range in consensus values $(44-47 \mu \mathrm{M})$. Suspended particles for chlorophyll $a$ determination, collected on GF/F filters, were wrapped in $\mathrm{Al}$ foil and stored at $-20^{\circ} \mathrm{C}$. The plant pigment was extracted into acetone (90\% v/v) and determined by fluorescence, following Parsons et al. (1984).

\section{Results and discussion}

\subsection{Master variables, nutrients, DOC and chlorophyll a}

Summary data $(x \pm 1 \sigma)$ for master variables, nutrients, DOC and chlorophyll $a$ for each tidal cycle survey at Restronguet Point are shown in Fig. 2. Also included are the daily river flows for the River Fal (the nearest gauged river; Fig. 1); these data (Fig. 2A) show that surveys were undertaken during contrasting hydrological conditions, with mean flows ranging from $0.72-4.93 \mathrm{~m}^{3} \mathrm{~s}^{-1}$. The greatest salinity range was observed in December $2002(S=30.3 \pm 3.5$; Fig. 2B), when the highest river flow was encountered at the maximum tidal range $(4.7 \mathrm{~m})$, while the most saline waters were observed during spring/summer surveys (up to $S=34.6$ ). Throughout, the lowest salinity values coincided with low water. The $\mathrm{pH}$, at around 8.2 (Fig. 2D), was typical for high-salinity estuarine waters, although lowest values occurred during winter $(7.97 \pm 0.08)$ and highest values during summer $(8.52 \pm 0.13)$. The higher summer values coincided with super-saturation of dissolved oxygen (116 $\pm 11 \%$; Fig. $2 \mathrm{E}$ ), indicating that phytoplankton production was important at this time and yielded increases in $\mathrm{pH}$. However, the oxygen super-saturation did not coincide with highest concentrations of chlorophyll $a$ (Fig. 2F). Concentrations of nitrate + nitrite were highest in the winter $(33 \pm 13 \mu \mathrm{M} \mathrm{N})$ and lowest in summer $(3.1 \pm 1.7 \mu \mathrm{MN})$ and were linked to relative changes in catchment run-off and algal growth (Fig. 2G and F). Ortho-phosphate concentrations were low (less than $0.31 \pm$ $0.05 \mu \mathrm{M}$ P), but with a seasonal cycle more complex than nitrate + nitrite, probably due to the influence of effluent inputs from sewage treatment works (Fig. 1A) (Langston et al., 2003).

\subsection{Concentrations and behaviour of $M e_{\text {tot }}$ and $M e_{d y n}$}

Concentration data $(x \pm 1 \sigma)$ for $\mathrm{Me}_{\text {tot }}$ and $\mathrm{Me}_{\mathrm{dyn}}$ for each tidal cycle at Restronguet Point are summarised in Fig. 3. Mean $\mathrm{Cu}_{\text {tot }}$ concentrations showed relatively little variation throughout the sampling period, at $78 \pm 45-126 \pm 100 \mathrm{nM}$ (Fig. 3A), with a minimum to maximum range of $4.97-315 \mathrm{nM}$ for all data. Mean concentrations of $\mathrm{Cu}_{\mathrm{dyn}}$ showed more variability $(13.3 \pm 6.3$ to $64.2 \pm 30.5 \mathrm{nM}$; range $1.7-190 \mathrm{nM}$ ) and values were generally higher during the winter high river flow periods. Mean concentrations of $\mathrm{Cd}_{\text {tot }}$ varied between $0.53 \pm 0.34$ and $2.69 \pm 2.49 \mathrm{nM}$ (Fig. 3B), with a range of $0.13-8.53 \mathrm{nM} \mathrm{Cd}_{\text {tot }}$ for all data. Concentrations of $\mathrm{Cd}_{\mathrm{dyn}}$ ranged from $0.55 \pm 0.81$ to $1.75 \pm 1.47 \mathrm{nM}$, with a range of $0.17-5.06 \mathrm{nM}$ and, as for $\mathrm{Cu}_{\mathrm{dyn}}$, mean values were higher during the winter. These total dissolved metal concentrations are in good agreement with recent data reported for Restronguet Point 

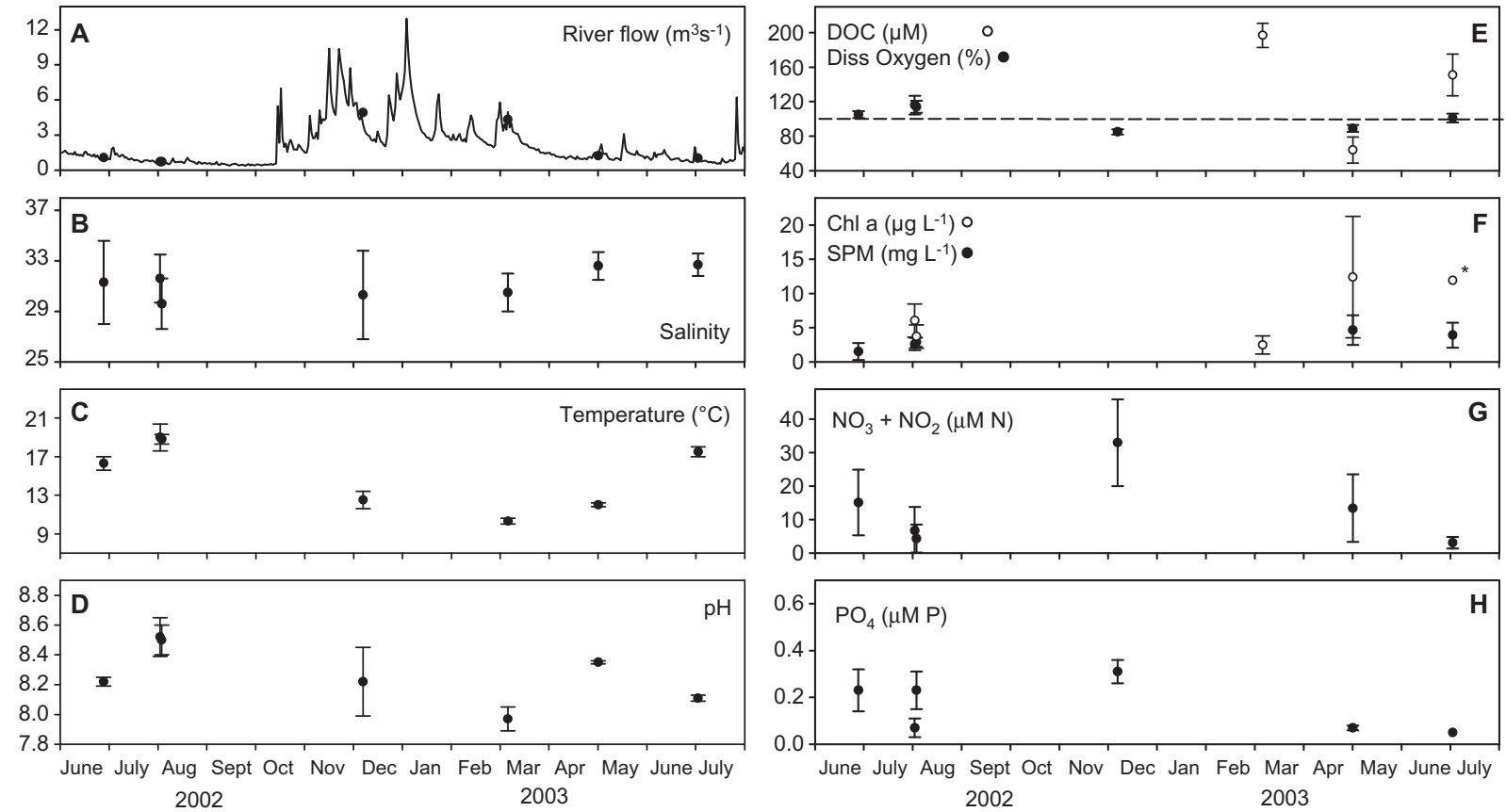

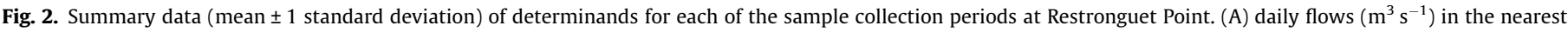

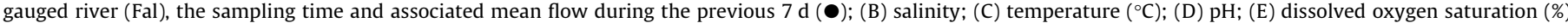

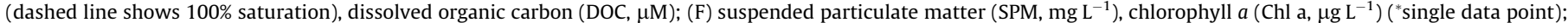

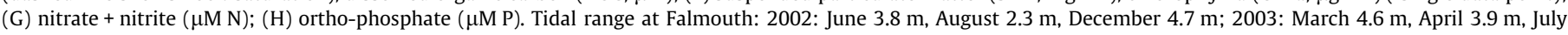
$3.7 \mathrm{~m}$.

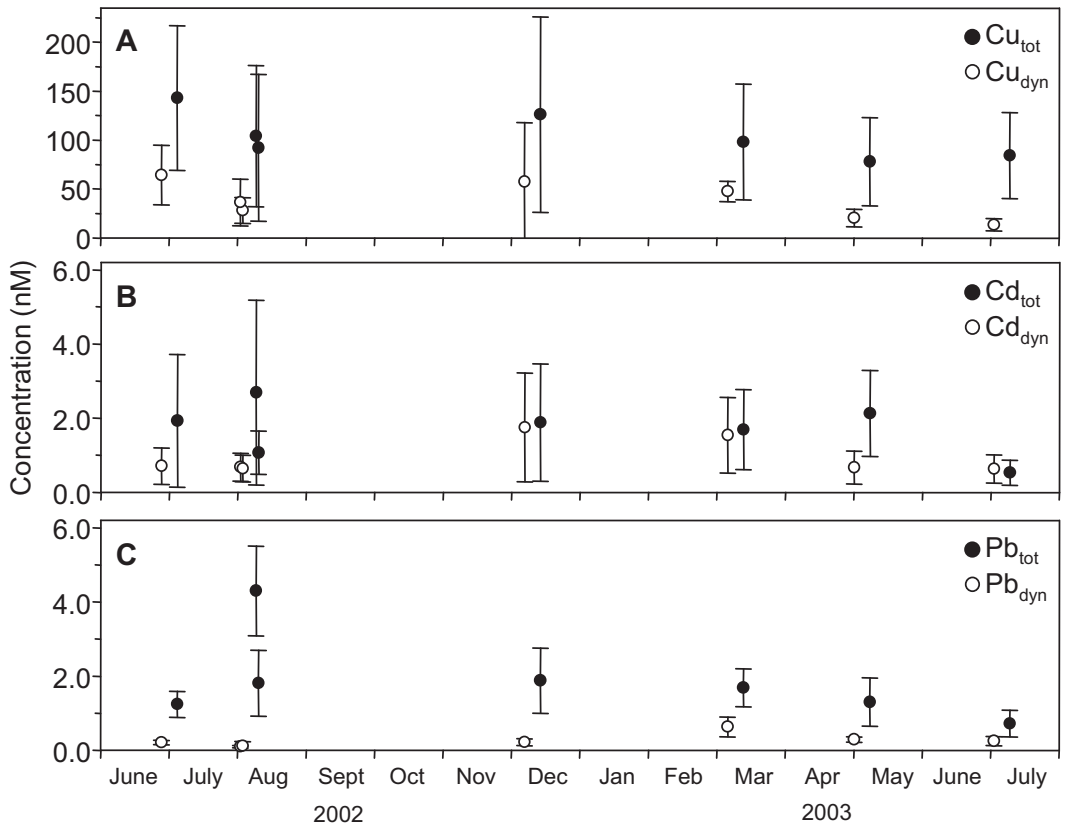

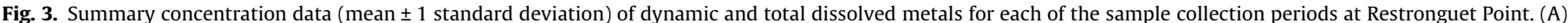
copper, (B) cadmium, (C) lead (all $\mathrm{nM}$ ). The data points for the dynamic and total fractions are offset to aid clarity.

by Langston et al. (2003); in this study the median metal concentrations were $110 \mathrm{nM} \mathrm{Cu}_{\text {tot }}$ (range $30-415 \mathrm{nM}$ ) and $1.8 \mathrm{nM} \mathrm{Cd}_{\text {tot }}$ (range $<1.8-80 \mathrm{nM}$ ). Mean concentrations of $\mathrm{Pb}_{\text {tot }}$ (Fig. 3C) were $1.24 \pm 0.35-4.30 \pm 1.21 \mathrm{nM}$ (range $0.35-5.74 \mathrm{nM}$ ), and as for $\mathrm{Cd}_{\mathrm{tot}}$, were lowest during July $2003(0.72 \pm 0.36 \mathrm{nM})$. In contrast to $\mathrm{Cu}_{\text {dyn }}$ and $\mathrm{Cd}_{\mathrm{dyn}}$, mean concentrations of $\mathrm{Pb}_{\mathrm{dyn}}$ were relatively uniform during the sampling period $(0.10 \pm 0.03-0.29 \pm 0.07 \mathrm{nM})$, except during March 2003, when higher concentrations were observed $\left(0.63 \pm 0.27 \mathrm{nM} \mathrm{Pb}_{\mathrm{dyn}}\right)$. The range in concentrations of $\mathrm{Pb}_{\mathrm{dyn}}$ was $0.038-1.30 \mathrm{nM}$ for all data.

Concentrations of dynamic and total dissolved $\mathrm{Cu}$ and $\mathrm{Cd}$ were generally highest near low water $( \pm 1 \mathrm{~h})$ and hence coincided with the lowest salinity during all surveys (e.g. Fig. 4A-D for June and December 2002). Freshwater endmember concentrations of $\mathrm{Cu}$ (355-3310 nM) and $\mathrm{Cd}(15.4-20 \mathrm{nM})$ in the River Carnon were higher than concentrations of $\mathrm{Cd}$ and $\mathrm{Cu}$ at Restronguet Point, 

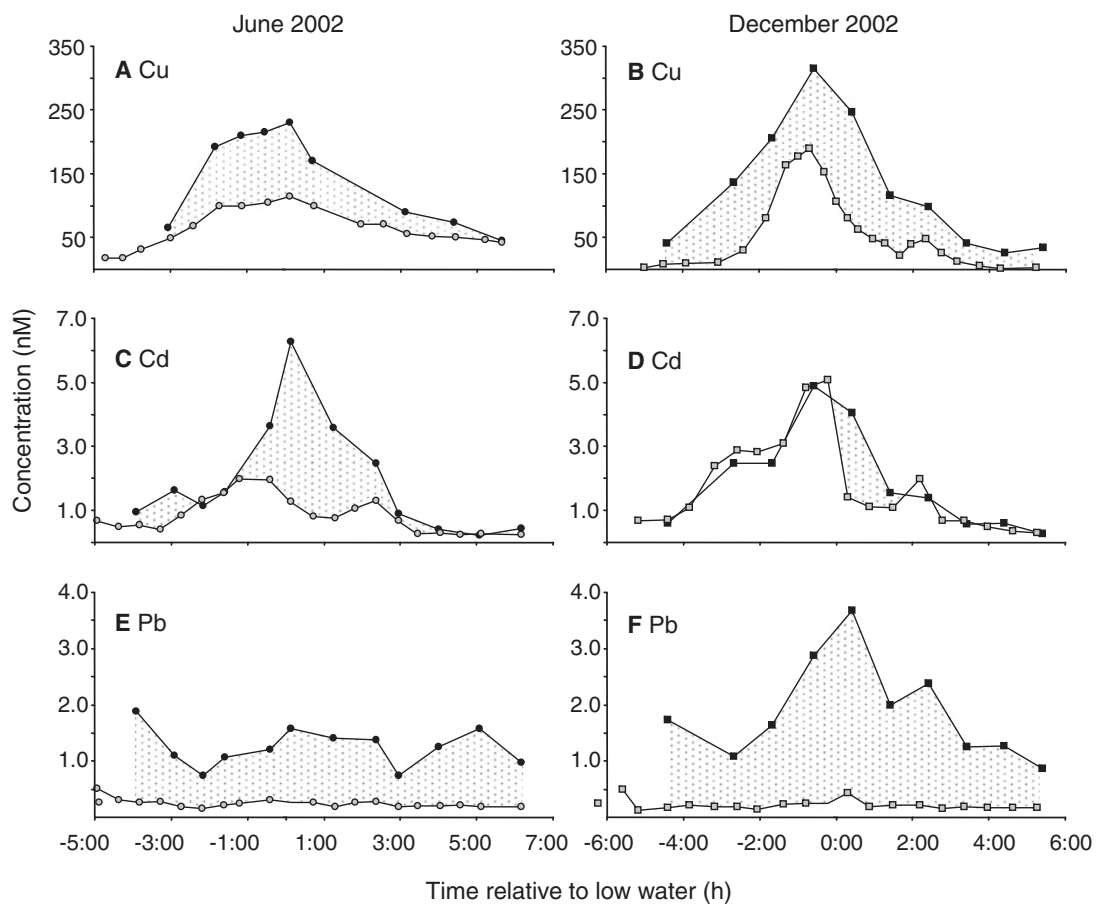

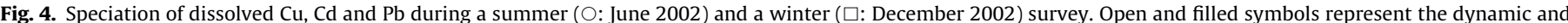

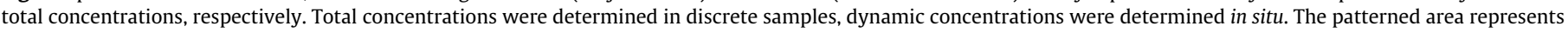
the non-dynamic, or colloidal, metal fraction, calculated by subtraction.

providing a strong source of dissolved metals to the estuary. Property-salinity analyses of the tidal cycle data indicate that concentrations of $\mathrm{Cd}_{\text {tot }}$ and $\mathrm{Cd}_{\mathrm{dyn}}$ were largely controlled by the mixing of metal-rich water from the River Carnon, at the head of Restronguet Creek, with marine water low in dissolved metals $\left(\mathrm{Cd}_{\mathrm{tot}}: r^{2}=0.64, p<0.0001, n=63 ; \mathrm{Cd}_{\mathrm{dyn}}: r^{2}=0.69, p<0.0001\right.$, $n=39$ ). Copper also correlated with salinity, although there was more scatter in the data $\left(\mathrm{Cu}_{\mathrm{tot}}: r^{2}=0.54, p<0.0001, n=51\right.$; $\mathrm{Cu}_{\mathrm{dyn}}$ : $\left.r^{2}=0.43, p<0.0001, n=69\right)$. Approximately linear inverse relationships between total dissolved $\mathrm{Cu}$ and $\mathrm{Cd}$, and salinity were observed along transects in Restronguet Creek in April and July 2003; similar patterns have also been reported by Langston et al. (2003). Concentrations of $\mathrm{Cu}$ and $\mathrm{Cd}$ in the surface bed sediments $(<100 \mu \mathrm{m}$ fraction) of Restronguet Creek are very high (21-30 $\mathrm{nmol} \mathrm{g}^{-1}$ DW Cd; $25 \times 10^{3}-71 \times 10^{3} \mathrm{nmol} \mathrm{g}^{-1}$ DW Cu) due to the mine waste inputs and the scatter in the propertysalinity relationships may be explained, in part, by benthic remobilisation of dissolved metals (Langston et al., 2003). Although reliable quantitative data on $\mathrm{Cu}$ release from the sediment have not been reported for this system, Skrabal et al. (2000) and references therein have directly measured fluxes of dissolved metals out of the sediment where pore water concentrations of metals are higher than in the overlying waters.

The concentrations of $\mathrm{Pb}_{\mathrm{dyn}}$ and $\mathrm{Pb}_{\text {tot }}$ exhibited no obvious pattern related to the tidal state during most of the deployments (Fig. 4E/F), although there was a weak negative correlation between $\mathrm{Pb}_{\text {dyn }}$ and salinity $\left(r^{2}=0.15, p=0.02, n=40\right)$. However, $\mathrm{Pb}_{\text {tot }}$ concentrations observed at low water at Restronguet Point (Fig. 4F) were always higher, sometimes markedly so, than the concentrations of $\mathrm{Pb}_{\text {tot }}(0.65-1.1 \mathrm{nM})$ determined at the tidal limit of the River Carnon during the same period. These elevated concentrations of $\mathrm{Pb}_{\text {tot }}$ at Restronguet Point indicate that there were additional sources of $\mathrm{Pb}$ in the estuary. Concentrations of $\mathrm{Pb}$ in the sediments of Restronguet Creek are in the range $1000-2700 \mathrm{nmol} \mathrm{g}^{-1} \mathrm{DW}$, making it one of the most lead contaminated estuaries studied (Pirrie et al., 2003). Therefore the Creek's extensive inter-tidal
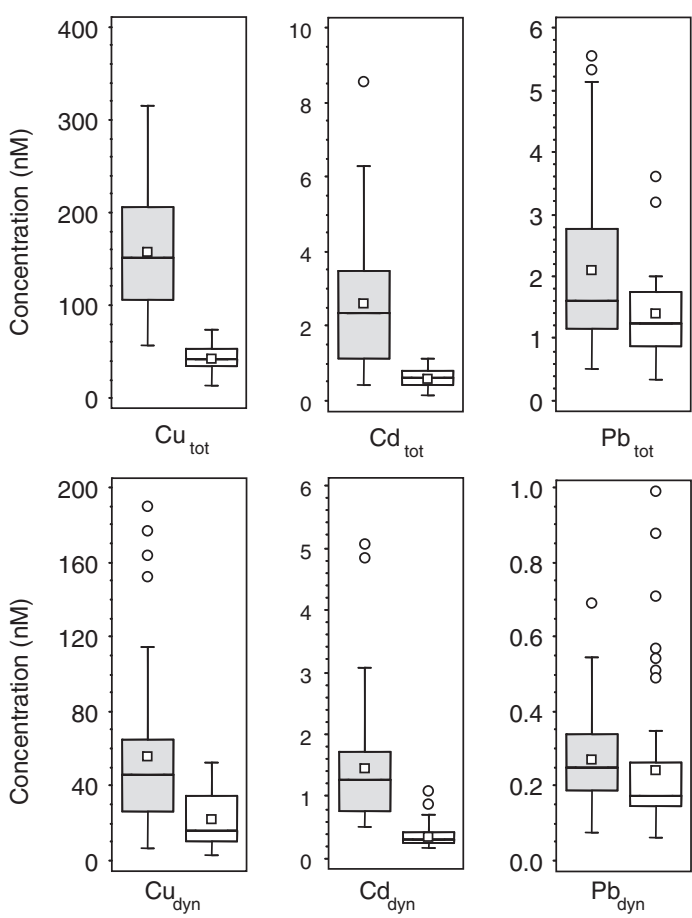

$2 \mathrm{~h}$ before to $2 \mathrm{~h}$ after LW ('peak' concentrations)

4 to $8 \mathrm{~h}$ before/after LW ('background' concentrations)

Fig. 5. Total and dynamic $\mathrm{Cu}, \mathrm{Cd}$ and $\mathrm{Pb}$ concentrations from seven tidal cycle surveys at Restronguet Point. Grey box: concentrations observed within $2 \mathrm{~h}$ either side of low water. White box: concentrations observed $4-6 \mathrm{~h}$ before or after low water. The central box covers the central $50 \%$ of data, the horizontal line is the median and the square is the mean.

mudflats are a reservoir, from which dissolved (including colloidal) lead may be released into the water column. 
The mobilisation of colloidal $\mathrm{Pb}$ and $\mathrm{Cu}$ from sediments has been reported as an important contributor to dissolved metal concentrations in other estuaries (e.g. Waeles et al., 2008). Furthermore, Boyden et al. (1979) reported a several-fold increase in SPM concentrations in bottom waters at Restronguet Point at low water, compared to high water, with concomitant increase in the particulate concentrations of $\mathrm{Fe}, \mathrm{Cu}$ and $\mathrm{Pb}$. Such a source of truly dissolved and/or colloidal metals would contribute to the scatter in the $\mathrm{Pb}$ and $\mathrm{Cu}$-salinity relationships observed in this study.

The distinctly tidally influenced profiles of $\mathrm{Cu}$ and $\mathrm{Cd}$ enabled the calculation of 'background' concentrations dominated by the marine end-member from data points obtained $4-6 \mathrm{~h}$ before or after LW, as well as 'peak' concentrations influenced by the inputs from the River Carnon ( $2 \mathrm{~h}$ either side of LW, Fig. 5). The average peak values for dynamic and total dissolved $\mathrm{Cu}$ and $\mathrm{Cd}$ were significantly higher than their respective background values ( $z$-test, $p \ll 0.05)$. There was no statistically significant difference between concentrations of $\mathrm{Pb}_{\mathrm{dyn}}$ or $\mathrm{Pb}_{\text {tot }}$ determined during the different time windows.

\subsection{Speciation of dissolved $\mathrm{Cu}, \mathrm{Cd}$ and $\mathrm{Pb}$}

The size of the colloidal pool, as a fraction of the total dissolved pool, was significantly different for each metal ( $z$-test, $p<0.05$; all data) and followed the sequence $77 \pm 17 \% \quad \mathrm{~Pb}_{\mathrm{col}}>60 \pm 25 \%$ $\mathrm{Cu}_{\mathrm{col}}>37 \pm 30 \% \mathrm{Cd}_{\mathrm{col}}$. Both the magnitude of the colloidal fraction and the sequence is comparable with other coastal and estuarine systems (see Section 1.2). During the spring and summer surveys, the fraction of $\mathrm{Cu}_{\mathrm{col}}$ dominated with an average of $67 \pm 14 \%$ and $56 \pm 26 \%$ of $\mathrm{Cu}_{\text {tot }}$ during the low water and non-low water periods of the tidal cycles, respectively (Fig. 4A). In December, however, the main increase in $\mathrm{Cu}_{\text {tot }}$ at the time of low water was in the dynamic fraction $\left(\mathrm{Cu}_{\mathrm{dyn}}\right)$, which formed $50 \%$ of $\mathrm{Cu}_{\text {tot }}$ (Fig. $4 \mathrm{~B}$ ), compared to a mean fraction of $20 \% \mathrm{Cu}_{\mathrm{dyn}}$ at background concentrations at this time. This suggests that in winter, when river flows were relatively high, dynamic $\mathrm{Cu}$ was more important, while in spring and summer, $\mathrm{Cu}$ in Restronguet Creek was largely present as non-dynamic complexes. The importance of terrestrially-derived DOC in determining Cu complexation behaviour has been reported for other estuaries (Shank et al., 2004a; Waeles et al., 2009). However, in these studies, the complexing ligands were hydrophobic, non-polar entities extractable by $\mathrm{C}_{18}$ resins and likely to form $\mathrm{Cu}$ complexes too strong (i.e. not sufficiently mobile and labile) to be detected by the VIP. Therefore, the increase in the dynamic fraction observed in Restronguet Creek during winter may have been due mainly to inorganic $\mathrm{Cu}$ complexes mobilised in a catchment markedly influenced by acid mine drainage. In the spring and summer of 2003 (no DOC data for 2002), there was no significant negative correlation between DOC and salinity (salinity range $0.43-34.4$ ), nor a positive correlation between chlorophyll $a$ and DOC. This suggests that the river was not an important source of terrestrial DOC during these periods and that suspended phytoplankton did not markedly contribute to the DOC pool in the Creek. There was, however, a weak positive linear correlation between $\mathrm{Cu}_{\text {tot }}$ and DOC concentrations $\left(r^{2}=0.23, p=0.03, n=20\right)$. Furthermore, Kawakami (2004) reported that dissolved $\mathrm{Cu}$ was strongly complexed in the Creek $\left(\log K_{\mathrm{CuL}}^{\prime}=10.8-12.8\right)$ during April and July 2003 (and August 2002). Potential sources of Cu-complexing DOC to the water column include the benthic sediment (Skrabal et al., 2000). In the Cape Fear River estuary, Shank et al. (2004a) reported that the benthic sediment was an important source of strong Cu-binding ligands $\left(\log K_{\mathrm{CuL}}^{\prime}>11\right)$ during the summer months, although their influence on $\mathrm{Cu}$ complexation was dependent on ambient concentrations of strong-binding ligands in the water column. While the fluxes of strongly complexing ligands and DOC from estuarine sediments are not always well correlated (Shank et al., 2004b), the positive correlation between $\mathrm{Cu}_{\text {tot }}$ and DOC in the current study is consistent with the sediment as a source of these moieties. The effluent from sewage treatment works may have also been a source of strong-binding ligands (van Veen et al., 2002), particularly during the low river flow periods, when effluent water makes up a larger proportion of surface water flow in this region (Langston et al., 2003). It is also possible that dissolved $\mathrm{Cu}$ is complexed by plankton-derived ligands (Dryden et al., 2007). However, Kawakami (2004) showed for August 2002, April and July 2003 that the ligands (phytochelatins and glutathione) produced by autochthonous plankton growth constituted a minor component $(<7 \%)$ of the total ligand concentration $(45-620 \mathrm{nM})$ that contributed the strong $\mathrm{Cu}$ complexation observed. In summary, the data suggest that relatively high concentrations of bioavailable $\mathrm{Cu}$ are present during low water in the winter, while in spring and summer an important colloidal phase reduces $\mathrm{Cu}$ bioavailability and potential toxicity.

Dissolved Cd exhibits a complex geochemistry in river estuaries. In both, freshwater and brackish-to-saline estuarine water, dissolved Cd can have a significant colloidal component, or very little. Furthermore, dissolved $\mathrm{Cd}$ appears to undergo dynamic changes in size distributions (e.g. < $1 \mathrm{kDa}, 1-10 \mathrm{kDa}, 10 \mathrm{kDa}-0.45 \mu \mathrm{m}$ ) along the salinity gradient (Powell et al., 1996). Presumably, changes in size distribution will exert an effect on the strength of ligand binding. In June and August 2002 and in April 2003, $\mathrm{Cd}_{\text {col }}$ increased with $\mathrm{Cd}_{\text {tot }}$, for example constituting a shift from $31 \%$ to $42 \% \mathrm{Cd}_{\mathrm{col}}$ at background concentrations to over $81 \% \mathrm{Cd}_{\mathrm{col}}$ at maximum concentrations at low water in June (Fig. 4C). In contrast, peak concentrations of $\mathrm{Cd}_{\text {tot }}$ resulted mainly from an increase in the dynamic fraction in December 2002 (Fig. 4D) and March and July 2003. The lack of a seasonal trend and the strong interaction between $\mathrm{Cd}$ and colloids in estuaries suggests that the estuarine speciation of Cd may have been controlled by a complex interplay of several processes: riverine $\mathrm{Cd}_{\mathrm{dyn}}$ inputs, a redistribution of riverine colloidal Cd from larger to smaller size fractions at increasing salinity in the estuary (Powell et al., 1996), Cd release from decomposing organic matter in the benthic compartment and/or release of $\mathrm{Cd}_{\mathrm{col}}$ from (re)-suspended inorganic colloids (Waeles et al., 2009). As the total Cd concentration in the fresh water input of the River Carnon was constant (15-20 nM) during all surveys, the flux into the estuary would have been lower during periods of low river flow, which coincided with surveys when the increase in Cd around low water was mainly colloidal (June/August 2002 and April 2003). During the December and March surveys, high river flow and riverine $\mathrm{Cd}$ flux may have partially masked estuarine processes, and riverine $\mathrm{Cd}_{\mathrm{dyn}}$ dominated the Cd increase at Restronguet Point at low water. This is consistent with the prevalence of free hydrated $\mathrm{Cd}$ ions in acidic river water and the tendency of Cd to form chloro-complexes at higher salinities (Chester, 2003).

The colloidal fraction of $\mathrm{Pb}$ ranged from $30 \%$ to $99 \%$ of $\mathrm{Pb}_{\text {tot }}$ (mean $80 \%$ ) and minima or maxima in this fraction were not associated with particular tidal stages ( $z$-test, $p \gg 0.05$ for difference between different times of the tidal cycle). The association of $\mathrm{Pb}$ with colloidal iron hydroxide phases, rather than with organic colloids has been shown to be important in its estuarine speciation (Waeles et al., 2008; Stolpe et al., 2010) and the presence of precipitated Fe phases and primary sulphide minerals in the sediment in the Restronguet Creek has been reported (Pirrie et al., 2003). The evolution of $\mathrm{Pb}$ speciation during individual tidal cycle studies (e.g. June and December 2002, Fig. 4E/F) indicates that the changes in $\mathrm{Pb}_{\text {tot }}$ resulted largely from variations in the colloidal fraction not associated with high/low water cycles. Furthermore, the riverine concentration of $\mathrm{Pb}$ was consistently below $\mathrm{Pb}_{\text {tot }}$ at Restronguet Point (see Section 3.2). These data suggest that $\mathrm{Pb}$ inputs to the water column resulted from the mobilisation of $\mathrm{Pb}$ associated with colloidal $\mathrm{Fe}$ phases in the sediment, induced by disturbances of surface sediments through tidal hydrodynamics and boating 
activities at the mouth of the Creek. While it is likely that oxidative release of metals from primary and secondary metal sulphides as a result of resuspension or bioturbation contributes to the overall metal load in the water column, oxidation rates of $\mathrm{PbS}$ have been shown to be too low (PbS is not affected by oxidation after $8 \mathrm{~h}$ suspension in oxic seawater, Simpson et al., 1998) to be significant on the time scale of a tidal cycle. This supports the suggestion that colloidal Fe oxide/hydroxide phases play the dominant role in the sediment/water interaction for $\mathrm{Pb}$.

\subsection{Impacts on biota}

The Environmental Quality Standard (EQS) for dissolved copper in saltwater/estuarine waters (78.7 $\mathrm{nM}$ annual average, European Commission (EC) Dangerous Substances Directive, DSD) was exceeded during all tidal cycle studies at Restronguet Point by peak concentrations of $\mathrm{Cu}_{\text {tot }}$ ( $2 \mathrm{~h}$ either side of low water, Fig. 5) and within Restronguet Creek itself (up to $3.30 \mu \mathrm{M} \mathrm{Cu}_{\text {tot }}$ ). Concentrations of $\mathrm{Cd}_{\text {tot }}$ and $\mathrm{Pb}_{\text {tot }}$ remained below the respective EQS values (120 nM Pb and $22.3 \mathrm{nM} \mathrm{Cd,} \mathrm{both} \mathrm{annual} \mathrm{averages} \mathrm{EC} \mathrm{DSD)} \mathrm{at}$ Restronguet Point and in the Creek (up to $20 \mathrm{nM} \mathrm{Cd}_{\text {tot }}$ and $4.2 \mathrm{nM}$ $\mathrm{Pb}_{\text {tot }}$ ). During all surveys, freshwater endmember concentrations of $\mathrm{Cu}_{\text {tot }}$ and $\mathrm{Cd}_{\text {tot }}$ in the River Carnon exceeded the relevant EQS values (1.6-440 $\mathrm{nM} \mathrm{Cu}$, depending on total hardness and $8.9 \mathrm{nM} \mathrm{Cd}$, both annual averages, EC DSD). This indicates that detrimental effects on species susceptible to contamination in the water column, such as phytoplankton, macroalgae and some macroinvertebrate species, arise throughout Restronguet Creek from dissolved copper alone, particularly during the ebb tide.

More specific information on toxicity is provided by the dynamic metal concentrations obtained during the tidal cycle studies at Restronguet Point, as dynamic metal species approximates the biologically available fraction (Buffle and Tercier-Waeber, 2005). However, there is a paucity of published data on the toxicity of the dynamic fraction. Therefore, assuming a salinity of 30, $\mathrm{pH} 8.2$ and that the dynamic $\mathrm{Cu}, \mathrm{Cd}$ and $\mathrm{Pb}$ fractions are made up entirely of inorganic complexes, minimum and maximum free metal ion concentrations were calculated for June and December 2002 surveys using the thermodynamic equilibrium modelling software MINEQL+ (Version 4.5, Schecher and McAvoy, 2003).

The calculated free cupric ion concentration varied between 0.12 and $14 \mathrm{nM} \mathrm{Cu}^{2+}$ in December and between 1.3 and $8.5 \mathrm{nM} \mathrm{Cu}^{2+}$ in June. These results show that cyanobacteria and many plankton species are likely to be highly compromised in the Creek, as studies showed that their viability declined at concentrations in the range 0.001-0.1 nM Cu${ }^{2+}$ (Brand et al., 1986; Sunda et al., 1987). Furthermore, larvae bioassays of higher organisms, such as sea urchin (Strongylocentrotus purpuratus), mussel (Mytilus galloprovincialis) and oyster (Crassostrea gigas), exhibited sensitivity toward $\mathrm{Cu}^{2+}$ at $\mathrm{EC}_{50} \leqslant 0.90 \mathrm{nM}, \mathrm{EC}_{50} \leqslant 0.06 \mathrm{nM}$ and $\mathrm{EC}_{50}=0.23 \pm 0.08 \mathrm{nM}$, respectively (Rivera-Duarte et al., 2005; Money, 2008), and hence the development of juveniles of such organisms is likely to be severely impaired at the study location.

The calculated minimal and maximal concentrations of $\mathrm{Cd}^{2+}$ and $\mathrm{Pb}^{2+}$ were in the sub-nanomolar range for both surveys $(0.009-$ $0.18 \mathrm{nM} \mathrm{Cd}^{2+}$ and $0.008-0.028 \mathrm{nM} \mathrm{Pb}^{2+}$ ). Phytoplankton species are less sensitive to $\mathrm{Pb}$ and $\mathrm{Cd}$ than to $\mathrm{Cu}$. For example, reduced growth rates have been reported for a range of coastal phytoplankton species at a free ion concentration of $\mathrm{Cd}^{2+}>23 \mathrm{nM}$ (Payne and Price, 1999), suggesting that $\mathrm{Cd}_{\mathrm{dyn}}$ in Restronguet Creek was below the effect threshold by at least two orders of magnitude. Money (2008) reported toxicity to $C$. gigas (abnormal larva development) with an $\mathrm{EC}_{50}=88.0 \pm 34.7 \mathrm{nM}$ for $\mathrm{Cd}^{2+}$ and $\mathrm{EC}_{50}=362 \pm 178 \mathrm{nM}$ for $\mathrm{Pb}^{2+}$, indicating that on their own neither $\mathrm{Cd}$ nor $\mathrm{Pb}$ present environmental hazards to macroinvertebrates in the Fal Estuary.
The data presented here suggest that the dynamic concentration of $\mathrm{Cu}(2.8-190 \mathrm{nM})$ in the Restronguet Creek is of the order of magnitude likely to have toxic effects on juveniles of coastal macroinvertebrate species, as well as negatively affect the even more sensitive phytoplankton community. Moreover, bioassay studies of metal mixtures have shown synergistic toxic effects (e.g. Kobayashi and Okamura, 2005) between metals, and therefore, the combination of enhanced $\mathrm{Cu}_{\mathrm{dyn}}, \mathrm{Cd}_{\mathrm{dyn}}$ and $\mathrm{Pb}_{\mathrm{dyn}}$ at low water is of concern. Furthermore, high total dissolved $\mathrm{Zn}$ and As concentrations (76-22900 nM Zn, 40-1250 nM As) have been reported for the Restronguet Creek (Langston et al., 2003), adding to the toxic burden.

\section{Conclusions}

A unique set of data has been presented that resolved the dynamic changes of $\mathrm{Cu}, \mathrm{Cd}$ and $\mathrm{Pb}$ speciation in an estuary impacted by the legacy of metal mining in its catchment. The information on dynamic metal species obtained in situ at high temporal resolution highlighted the enhanced concentrations of potential toxic forms of $\mathrm{Cu}$ and $\mathrm{Cd}$ when the influence of the riverine contamination arising from mine drainage is highest, i.e. during times of low water and/or high river water discharge. Changes in dynamic and colloidal metal concentrations in the water column highlighted the different behaviour of $\mathrm{Cu}, \mathrm{Cd}$ and $\mathrm{Pb}$ in this estuary. This data set combined total metal concentrations along the salinity gradient, speciation data for tidal cycles and auxiliary data, which allowed to infer that important interactions between dissolved $\mathrm{Pb}$ and $\mathrm{Cd}$ and the benthic compartment took place. These data show that important fluctuations in metal toxicity can occur in estuaries over a range of time scales, from minutes to seasons. Furthermore, these fluctuations are more complex than simple relations to river inputs, the stage of the tide or seasonal factors. This study illustrates that in order to understand the potential impact of contamination within the dynamic coastal environment, biologically relevant fractions of metals have to be studied in situ and at sufficiently high resolution.

\section{Acknowledgements}

Financial support from European Union Framework 5 Project IMTEC (In situ automated Monitoring of Trace metal speciation in Estuaries and Coastal zones), Contract EVK3-CT-2000-000036 and from NERC (GT 4/98/MS/234) is acknowledged. The authors thank Jacques Buffle and Mary-Lou Tercier-Waeber for their support. Graham Carter undertook the salinometer determinations and provided guidance on the use of the CTD, and Silvia Kawakami provided some of the chlorophyll $a$ data.

\section{References}

Badr, E.-S.A., Achterberg, E.P., Hill, S.J., Tappin, A.D., Braungardt, C.B., 2003. Determination of dissolved organic nitrogen in natural waters using high temperature catalytic oxidation. TRAC - Trend. Anal. Chem. 22, 819-827.

Boyden, C.R., Aston, S.R., Thornton, I., 1979. Tidal and seasonal variations of trace elements in two Cornish estuaries. Estuar. Coast. Mar. Sci. 9, 303-317.

Braithwaite, R.A., Cadavid Carrascosa, M.C., McEvoy, L.A., 2007. Biofouling of salmon cage netting and the efficacy of a typical copper-based antifoulant. Aquaculture 262, 219-226.

Brand, L.E., Sunda, W.G., Guillard, R.R.L., 1986. Reduction of marine phytoplankton reproduction rates by copper and cadmium. J. Exp. Mar. Biol. Ecol. 96, 225-250.

Braungardt, C.B., Achterberg, E.P., Axelsson, B., Buffle, J., Graziottin, F., Howell, K.A. Illuminati, S., Scarponi, G., Tappin, A.D., Tercier-Waeber, M.-L., Turner, D., 2009 Analysis of dissolved metal fractions in coastal waters: An inter-comparison of five voltammetric in situ profiling (VIP) systems. Mar. Chem. 114, 47-55.

Buffle, J., Tercier-Waeber, M.-L., 2005. Votlammetric environmental trace-metal analysis and speciation: from laboratory to in situ measurements. TRAC Trend. Anal. Chem. 24, 172-191.

Burlinson, F.C., Lawrence, A.J., 2007. A comparison of acute and chronic toxicity tests used to examine the temporal stability of a gradient in copper tolerance of Hediste diversicolor from the Fal estuary, Cornwall, UK. Mar. Pollut. Bull. 54, 66-71. 
Chester, R., 2003. Marine Geochemistry, second ed. Blackwell Science Ltd., Oxford.

Dryden, C.L., Gordon, A.S., Donat, J.R., 2007. Seasonal survey of copper-complexing ligands and thiol compounds in a heavily utilized, urban estuary: Elizabeth River, Virginia. Mar. Chem. 103, 276-288.

European Environment Agency, 2003. Europe's Environment: the Third Assessment Environmental Assessment Report No. 10. Luxembourg Office for Official Publications of the European Union.

European Environment Agency, 2005. The European Environment - State and Outlook. European Environment Agency, Copenhagen.

Howell, K.A., Achterberg, E.P., Braungardt, C.B., Tappin, A.D., Turner, D.R., Worsfold, P.J., 2003. The determination of trace metals in estuarine and coastal waters using a voltammetric in situ profiling system. Analyst 128, 734-741.

Howell, K.A., Achterberg, E.P., Tappin, A.D., Worsfold, P.J., 2006. Colloidal metals in the Tamar estuary and their influence on metal fractionation by membrane filtration. Environ. Chem. 3, 199-207.

Kawakami, S.K., 2004. Particulate Phytochelations as an Indication of Metal Stress in Natural Waters. PhD Thesis, University of Plymouth Faculty of Science.

Kobayashi, N., Okamura, H., 2005. Effects of heavy metals on sea urchin embryo development. Part 2 . Interactive toxic effects of heavy metals in synthetic mine effluents. Chemosphere 61, 1198-1203.

Langston, W.J., Chesman, B.S., Burt, G.R., Hawkins, S.J., Readman, J., Worsfold, P., 2003. Characterisation of the South West European Marine Sites: the Fal and Helford cSAC. Occasional Publication of the MBA No. 8. Marine Biological Association of the United Kingdom, Plymouth.

Lyvén, B., Hassellöv, M., Turner, D.R., Haraldsson, C., Andersson, K., 2003. Competition between iron- and carbon-based colloidal carriers for trace metals in a freshwater assessed using flow field-flow fractionation coupled to ICPMS. Geochim. Cosmochim. Acta 67, 3791-3802.

Money, C., 2008. Trace Metal Chemical Speciation and Acute Toxicity to Pacific Oyster Larvae. PhD Thesis, University of Plymouth Faculty of Science.

Parsons, T.R., Maita, Y., Lalli, C.M., 1984. A Manual of Chemical and Biological Methods for Seawater Analysis. Pergamon Press, Oxford.

Payne, C.D., Price, N.M., 1999. Effects of cadmium toxicity on growth and elemental composition of marine phytoplankton. J. Phycol. 35, 293-302.

Pirrie, D., Power, M.R., Rollinson, G., Camm, G.S., Huges, S.H., Butcher, A.R., Huges, P., 2003. The spatial distribution and source of arsenic, copper, tin and zinc within the surface sediments of the Fal Estuary, Cornwall, UK. Sedimentology 50, 579595.

Powell, R.T., Landing, W.M., Bauer, J.E., 1996. Colloidal trace metals, organic carbon and nitrogen in a southeastern US estuary. Mar. Chem. 55, 165-176.

Rivera-Duarte, I., Rosen, G., Lapota, D., Chadwick, D.B., Kear-Padilla, L., Zirino, A. 2005. Copper toxicity to larval stages of three marine invertebrates and copper complexation capacity in San Diego Bay, California. Environ. Sci. Technol. 39, 1542-1546.

Schecher, W.D., McAvoy, D.C., 2003. MINEQL + Chemical Equilibrium Modeling System. 2nd [4.5 for Windows]. Hallowell, Maine, USA, Environmental Research.

Shank, G.C., Skrabal, S.A., Whitehead, R.F., Kieber, R.J., 2004a. Fluxes of strong Cucomplexing ligands from sediments of an organic-rich estuary. Estuar. Coast. Shelf. Sci. 60, 349-358.
Shank, G.C., Skrabal, S.A., Whitehead, R.F., Kieber, R.J., 2004b. Strong copper complexation in an organic-rich estuary: the importance of allochthonous dissolved organic matter. Mar. Chem. 88, 21-39.

Simpson, S.L., Apte, S.C., Batley, G.E., 1998. Effect of short-term resuspension events on trace metal speciation in polluted anoxic sediments. Environ. Sci. Technol. 32, 620-625.

Skrabal, S.A., Donat, J.R., Burdige, D.J., 2000. Pore water distributions of dissolved copper and copper-complexing ligands in estuarine and coastal marine sediments. Geochim. Cosmochim. Acta 64, 1843-1857.

Slaveykova, V.I., Wilkinson, K.J., 2005. Predicting the bioavailability of metals and metal complexes: critical review of the Biotic Ligand Model. Environ. Chem. 2, 9-24.

Stolpe, B., Guo, L., Shiller, A.M., Hassellöv, M., 2010. Size and composition of colloidal organic matter and trace elements in the Mississippi River, Pearl River and the northern Gulf of Mexico, as characterized by flow field-flow fractionation. Mar. Chem. 118, 119-128.

Sunda, W.G., Tester, P.A., Huntsman, S.A., 1987. Effects of cupric and zinc ion activities on the survival and reproduction of marine copepods. Mar. Biol. 94, 203-210.

Tercier-Waeber, M.-L., Buffle, J., Koudelka-Hep, M., Graziottin, F., 2002. Submersible voltammetric probes for real-time continuous monitoring of trace elements in natural aquatic systems. In: Taillefert, M., Rozan, T.F. (Eds.), Environmental Elecgtrochemistry, Analyses of Trace Element Biogeochemistry. American Chemical Society.

Tercier-Waeber, M.-L., Confalonieri, F., Riccardi, G., Sina, A., Nöel, S., Buffle, J., Graziottin, F., 2005. Multi physical-chemical profiler for real-time in situ monitoring of trace metal speciation and master variables: development, validation and field applications. Mar. Chem. 97, 216-235.

The Royal Society, 2005. Ocean Acidification due to Increasing Atmospheric Carbon Dioxide. Policy Document 12/05. The Royal Society, London.

van Veen, E., Burton, N., Comber, S., Gardner, M., 2002. Speciation of copper in sewage effluent and its toxicity to Daphnia magna. Environ. Toxicol. Chem. 21, 275-280.

Waeles, M., Tanguy, V., Lespes, G., Riso, R.D., 2008. Behaviour of colloidal trace metals $(\mathrm{Cu}, \mathrm{Pb}$ and $\mathrm{Cd})$ in estuarine waters: an approach using frontal ultrafiltration (UF) and stripping chronopotentiometric methods (SCP). Estuar. Coast. Shelf Sci. 80, 538-544.

Waeles, M., Riso, R.D., Cabon, J.Y., Maguer, J.-F., 2009. Speciation of dissolved copper and cadmium in the Loire estuary and over the North Biscay continental shelf in spring. Estuar. Coast. Shelf Sci. 84, 139-146.

Warwick, R.M., 2001. Evidence for the effects of metal contamination on the intertidal macrobenthic assemblages of the Fal Estuary. Mar. Pollut. Bull. 42, $145-148$.

Wells, M.L., Kozelka, P.B., Bruland, K.W., 1998. The complexation of 'dissolved' Cu, $\mathrm{Zn}, \mathrm{Cd}$ and $\mathrm{Pb}$ by soluble and colloidal organic matter in Naragansett Bay, RI. Mar. Chem. 62, 203-217.

Wen, L-S., Santschi, P., Gill, G.A., Paternostro, C.L, 1999. Estuarine trace metal distributions in Galveston Bay: importance of colloidal forms in the speciation of the dissolved phase. Mar. Chem. 63, 185-212. 